\title{
THE INFLUENCE OF SCHOOL RESOURCES ON LEARNING OUTCOMES (AFFECTIVE SKILLS' DEVELOPMENT) OF PUPILS IN SPECIAL SCHOOLS IN OSUN STATE, NIGERIA
}

\author{
*Ifeoluwa Samuel OLUYIMIDE
}

\&

\author{
ADELEKE Ayobami G., Ph.D \\ Institute of Education, \\ Obafemi Awolowo University, Ile-Ife, Nigeria \\ ifeoluwaoluyimide@gmail.com, ag_leke@oauife.edu.ng \\ DOI: 10.31364/SCIRJ/v8.i9.2020.P0920806 \\ http://dx.doi.org/10.31364/SCIRJ/v8.i9.2020.P0920806
}

\begin{abstract}
The study investigated the availability of teaching and learning resources in schools tagged "special". The study
\end{abstract} employed a descriptive survey research design. The study population consisted of 2,370 pupils in special schools across Osun State, Nigeria. A multistage sampling procedure was used to select schools purposively sampled for the study. The purpose was the availability of special schools in the LGAs. Two special schools were purposefully selected in the two Local Government Areas (LGAs). The total enumeration technique was used to sample 65 pupils in 2 intact classes for the study. Two adapted instruments were used for the study. The first was a checklist on "Resource Availability and Adequacy which was used to determine the availability and adequacy of resources in sampled schools and; an Observation Checklist on Affective Skill Development (OCASD) which was used to collect data on pupils' demonstration of affective skills. The data collected were analysed descriptively. The study revealed that most teaching and learning resources needed to facilitate challenged pupils' learning in school are tersely available. The impact of the available instruments is significant on the total model values of 2.8 and 2.7 and the two schools respectively. The study concluded that given adequate teaching-learning resources, special education schools would boost learning outcomes of pupils in special schools.

Index Terms: School Resources, Special Needs, Affective Skill Development, Influence

www.scirj.org

(C) 2020, Scientific Research Journal

http://dx.doi.org/10.31364/SCIRJ/v8.i9.2020.P0920806

This publication is licensed under Creative Commons Attribution CC BY. 


\section{Introduction}

Over the years, education has been seen as one of the best instruments to change and improve the world. Education as popularly known is the best legacy. However, the word education is from the Latin words 'educare' which means 'to care' and 'educere' which means 'to lead'. All these words mean the act of teaching or training, bring up and lead forth, respectively. The primary purpose of teaching at any level of education is to bring a fundamental change in the learner (Tebabal and Kahssay, 2011). To facilitate the process of knowledge transmission, spontaneous learning; teachers should apply suitable teaching methods that best suit specific objectives. Therefore, it is basic to mention that learning is best carried out when learners can showcase acceptable values, norms, and philosophies that relate to that of society.

However, it is worthy of note that all children are important and they should be exposed to functional education without depriving them of this right because of their colours, races, special needs, exception, families, affiliation, etc. Aduola (2011) pointed out that education should not only be extended to all children across the globe but all children should be taught well and preciously. According to research by Bruns (2010), Special Schools (SS) are designed specifically for pupils with special needs. Pupils in SS are learners who have one disability or the other (Turnbull 2002). They might have been diagnosed with a genetic condition that is associated with intellectual disability, developmental disorder, visual or hearing disabilities, or other disabilities (Bruns, 2010).

Special pupils, simply put, are learners who need special attention. Bruns (2010) further stated that 'Special Needs' is a term used in clinical diagnostic and functional development to describe individuals who require assistance for disabilities that may be medical, mental, or psychological. Pupils with special needs are learners who need assistance for their disabilities that may be medical, mental, or psychological. On the norm, Special Schools (SS) are meant to be grossly supplied will all forms of human and non-human school resources for the active learning of the pupils. However, studies by Bruns (2010), Hooker and Denker (2014), and Adeleke (2017) have constantly shown that a larger percentage of special schools in Nigeria are predominantly lagging in the adequate use of available school resources for teaching pupils with special needs most especially, building their affective skills.

School resources are undoubtedly important and schools in most countries, even in the developed world, would benefit from better buildings, more equipment and books, smaller classes, and more skillful teachers with higher morale (Thousand, 2007). In the same vein, school resources can be psychological and emotional attitudes and attributes of professionals and para-professionals working in the school; like teachers, care-givers, food vendors, security men, health officers, and so on. The social, economic, cultural, and political structures of the developed countries are largely determined by the schools. While the schools are affected by social changes and developments, they are also the sites where these changes are initiated. In other words, the schools both start and

www.scirj.org

(C) 2020, Scientific Research Journal

http://dx.doi.org/10.31364/SCIRJ/v8.i9.2020.P0920806

This publication is licensed under Creative Commons Attribution CC BY. 
are affected by all these changes. Schools are expected to furnish, develop, and make learners better with the virtues and responsibilities of good citizens and promote the relationship between the people through the right use of school resources.

Hooker and Denker (2014) defined affective skills as such which deal with the ability of a learner to attend to, respond, and value others. Ajayi (2017) corroborated that affective skills play an undeniable role in education. Affective skills enable pupils to express innate emotions and feelings like receiving, responding, valuing, organization, and characterization. The affective skills enable learners to show love to one another and also communicate and socialise with themselves in the school and after. This is an essential skill that, when developed in a learner, he or she can easily get rid of challenges like low-self-esteem and low demonstration of potentials, then meets up with making life better for his or her and others.

\section{Purpose of the Study}

The purpose of this study is to investigate the influence of school resources on learning outcomes of pupils in special schools in Osun State, Nigeria.

The three (3) specific objectives of the study are to

i. investigate the availability of school resources in special schools in Osun State;

ii. determine the adequacy of available school resources in special schools in the study area, and

iii. investigate the influence of school resources on the affective skills of pupils in special schools in the study area.

\section{Research Questions}

The following questions were raised to guide the study

1. What are the school resources available in special schools in Osun State?

2. How adequate are the available school resources in special schools in the study area?

3. What is the influence of school resources on the affective skills of pupils in special schools in the study area?

\section{Population, Sample, and Sampling Techniques}

The population of the study consisted of all pupils in special schools in Osun State. A multistage sampling technique was used for the study. Two Local Government Areas (LGAs) were purposefully sampled for the study. The purpose is the availability of special schools in the LGAs. Two special schools were purposefully selected in the two Local Government Areas (LGAs). The LGAs

www.scirj.org

(C) 2020, Scientific Research Journal

http://dx.doi.org/10.31364/SCIRJ/v8.i9.2020.P0920806

This publication is licensed under Creative Commons Attribution CC BY. 
were Ilesa East and Ife East. Total enumeration sampling technique was used to select pupils for the study, that all pupils in all classes in the special schools were used.

\section{Research Instrument(s)}

Two self-designed instruments were used for the study. They were; a checklist on "Resource Availability and Adequacy for Teaching Pupils in Special Schools (RAATPSS)” and “Observation Checklist on Pupils' Affective Skill Development (OCPASD). The RAATPSS was used by the researcher to determine the availability and adequacy of resources in the sampled schools. Also, the OCPASD was used by the researcher to collect data on pupils' demonstration of affective skills.

\section{Results}

Research Question 1: What are the school resources available in special schools in the study area?

Research Question 2: How adequate are the available school resources in special schools in the study area?

Table 1: Availability of school resources and its adequacy for school 1

\begin{tabular}{|c|c|c|c|c|}
\hline School Resources & $\begin{array}{l}\text { Available School } \\
\text { Resources }\end{array}$ & No & Comments & Remarks \\
\hline \multirow[t]{6}{*}{ School infrastructures } & Classroom(s) & 3 & 60 pupils/5 Units & Adequate \\
\hline & Chair(s) and Table(s) & Many & Made of wood & Adequate \\
\hline & Assembly ground(s) & 1 & Open field & Not Adequate \\
\hline & School office(s) & 1 & 8 teachers & Inadequate \\
\hline & $\begin{array}{l}\text { Administrative } \\
\operatorname{block}(\mathrm{s})\end{array}$ & 1 & 60 pupils & Adequate \\
\hline & $\begin{array}{l}\text { Toilets and } \\
\text { bathroom(s) }\end{array}$ & 4 & 60 pupils & Inadequate \\
\hline Sport facilities & \multicolumn{2}{|l|}{ None } & & Not Adequate \\
\hline Non-professional Staff & \multicolumn{2}{|l|}{ None } & & Not Adequate \\
\hline $\begin{array}{l}\text { Psychological and Health Professional } \\
\text { Staff }\end{array}$ & \multicolumn{2}{|l|}{ None } & & Not Adequate \\
\hline Vocational Training Facilities & \multicolumn{2}{|l|}{ None } & & Not Adequate \\
\hline \multirow[t]{4}{*}{ Special Needs Equipment } & Personal laptop(s) & 1 & 60 pupils & Not Adequate \\
\hline & Typewriter(s) & 3 & 60 pupils & Not Adequate \\
\hline & Braille(s) & 2 & 60 pupils & Not Adequate \\
\hline & Closed Circuit TV(s) & 1 & 60 pupils & Not Adequate \\
\hline
\end{tabular}

Table 2: Adequacy of the available school resources for school 2

\begin{tabular}{|l|l|l|l|l|}
\hline School Resources & $\begin{array}{l}\text { Available School } \\
\text { Resources }\end{array}$ & No & Comments & Remarks \\
\hline \multirow{2}{*}{ School infrastructures } & Classroom(s) & 7 & 65 pupils & \\
\cline { 2 - 5 } & Chair(s) and Table(s) & Many & Made of wood & Adequate \\
\cline { 2 - 5 } & Assembly ground(s) & 1 & Open field & Adequate \\
\hline
\end{tabular}




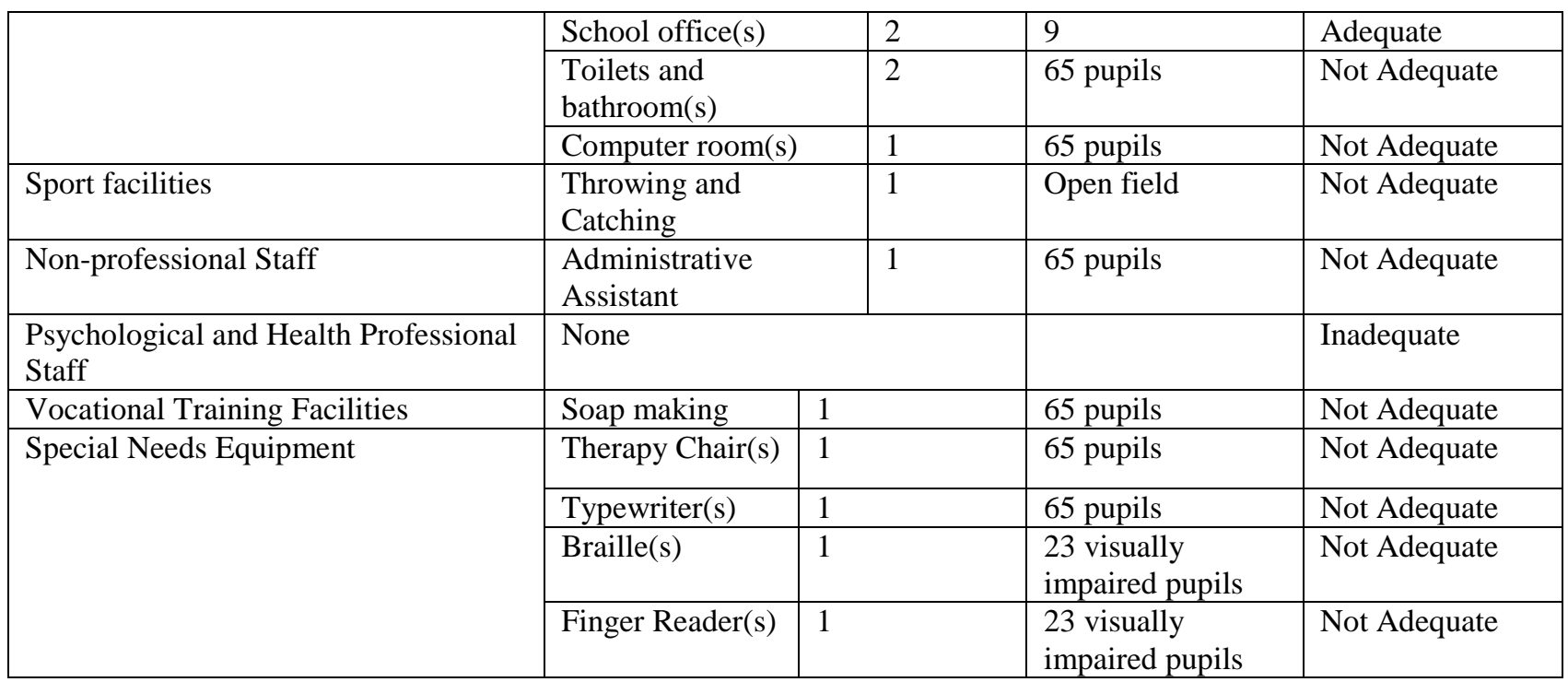

Research Objective 3: What is the influence of school resources on the affective skills of pupils in special schools in the study area?

Table 3: Influence of school resources on the affective skills of pupils in special school 1

\begin{tabular}{|c|c|c|c|c|c|c|c|c|}
\hline Skill & Verb & No & Min. & Max. & Mean & Std. d. & Mode & $\begin{array}{l}\text { Total } \\
\text { Average } \\
\text { Mode }\end{array}$ \\
\hline \multirow[t]{5}{*}{ Receiving } & Ability to hear & 60 & 1.00 & 4.00 & 2.01 & 0.72 & 2 & \multirow[t]{5}{*}{2.2} \\
\hline & Ability to listen & 60 & 1.00 & 4.00 & 2.17 & 0.67 & 2 & \\
\hline & Ability to ask & 60 & 1.00 & 4.00 & 2.23 & 0.70 & 2 & \\
\hline & Ability to feel & 60 & 1.00 & 4.00 & 2.32 & 0.65 & 2 & \\
\hline & Ability to concentrate & 60 & 1.00 & 4.00 & 2.45 & 0.70 & 3 & \\
\hline \multirow[t]{5}{*}{ Responding } & Ability to react & 60 & 1.00 & 4.00 & 2.47 & 0.65 & 2 & \multirow[t]{5}{*}{2.8} \\
\hline & Ability to clarify & 60 & 1.00 & 4.00 & 2.48 & 0.75 & 3 & \\
\hline & Ability to contribute & 60 & 1.00 & 4.00 & 2.60 & 0.67 & 3 & \\
\hline & Ability to perform & 60 & 1.00 & 4.00 & 2.58 & 0.74 & 3 & \\
\hline & Ability to answer & 60 & 1.00 & 4.00 & 2.68 & 0.68 & 3 & \\
\hline \multirow[t]{5}{*}{ Valuing } & Ability to argue & 60 & 1.00 & 4.00 & 2.63 & 0.76 & 3 & \multirow[t]{5}{*}{3.0} \\
\hline & Ability to challenge & 60 & 1.00 & 4.00 & 2.62 & 0.74 & 3 & \\
\hline & Ability to critique & 60 & 1.00 & 4.00 & 2.58 & 0.79 & 3 & \\
\hline & Ability to form & 60 & 1.00 & 4.00 & 2.65 & 0.73 & 3 & \\
\hline & Ability to justify & 60 & 1.00 & 4.00 & 2.58 & 0.83 & 3 & \\
\hline \multirow[t]{5}{*}{ Oragnisation } & Ability to build & 60 & 1.00 & 4.00 & 2.60 & 0.76 & 3 & \multirow[t]{5}{*}{3.0} \\
\hline & Ability to relate & 60 & 1.00 & 4.00 & 2.62 & 0.83 & 3 & \\
\hline & Ability to arrange & 60 & 1.00 & 4.00 & 2.70 & 0.77 & 3 & \\
\hline & Ability to reconcile & 60 & 1.00 & 4.00 & 2.65 & 0.78 & 3 & \\
\hline & Ability to modify & 60 & 1.00 & 4.00 & 2.68 & 0.77 & 3 & \\
\hline
\end{tabular}




\begin{tabular}{|c|c|c|c|c|c|c|c|c|}
\hline \multirow[t]{5}{*}{ Internalising } & Ability to act & 60 & 1.00 & 4.00 & 2.65 & 0.76 & 3 & \multirow[t]{5}{*}{3.0} \\
\hline & Ability to practice & 60 & 1.00 & 5.00 & 2.62 & 0.78 & 3 & \\
\hline & Ability to incorporate & 60 & 1.00 & 5.00 & 2.58 & 0.83 & 3 & \\
\hline & Ability to acquire & 60 & 1.00 & 5.00 & 2.57 & 0.87 & 3 & \\
\hline & $\begin{array}{l}\text { Ability to be } \\
\text { consistent }\end{array}$ & 60 & 1.00 & 5.00 & 2.55 & 0.93 & 3 & \\
\hline
\end{tabular}

Table 4.: Influence of school resources on the affective skills of pupils in special school 2

\begin{tabular}{|c|c|c|c|c|c|c|c|c|}
\hline Skill & Verb & No & Min. & Max. & Mean & Std. d. & Mode & $\begin{array}{l}\text { Total } \\
\text { Average } \\
\text { Mode }\end{array}$ \\
\hline \multirow[t]{5}{*}{ Receiving } & Ability to hear & 65 & 1.00 & 5.00 & 2.57 & .85 & 2 & \multirow[t]{5}{*}{2.0} \\
\hline & Ability to listen & 65 & 1.00 & 5.00 & 2.63 & .82 & 2 & \\
\hline & Ability to ask & 65 & 1.00 & 5.00 & 2.58 & .86 & 2 & \\
\hline & Ability to feel & 65 & 1.00 & 5.00 & 2.54 & .67 & 2 & \\
\hline & Ability to concentrate & 65 & 1.00 & 5.00 & 2.63 & .86 & 2 & \\
\hline \multirow{5}{*}{ Responding } & Ability to react & 65 & 1.00 & 5.00 & 2.64 & .86 & 3 & \multirow{5}{*}{3.0} \\
\hline & Ability to clarify & 65 & 1.00 & 5.00 & 2.73 & .85 & 3 & \\
\hline & Ability to contribute & 65 & 1.00 & 5.00 & 2.66 & .82 & 3 & \\
\hline & Ability to perform & 65 & 1.00 & 5.00 & 2.75 & .90 & 3 & \\
\hline & Ability to answer & 65 & 1.00 & 5.00 & 2.71 & .91 & 3 & \\
\hline \multirow[t]{5}{*}{ Valuing } & Ability to argue & 65 & 1.00 & 5.00 & 2.71 & .96 & 2 & \multirow[t]{5}{*}{2.8} \\
\hline & Ability to challenge & 65 & 1.00 & 5.00 & 2.75 & .87 & 3 & \\
\hline & Ability to critique & 65 & 1.00 & 5.00 & 2.88 & .91 & 3 & \\
\hline & Ability to form & 65 & 1.00 & 5.00 & 2.72 & .80 & 3 & \\
\hline & Ability to justify & 65 & 1.00 & 5.00 & 2.74 & .85 & 3 & \\
\hline \multirow[t]{5}{*}{ Oragnisation } & Ability to build & 65 & 2.00 & 5.00 & 2.71 & .76 & 2 & \multirow[t]{5}{*}{2.2} \\
\hline & Ability to relate & 65 & 2.00 & 5.00 & 2.71 & .80 & 2 & \\
\hline & Ability to arrange & 65 & 1.00 & 5.00 & 2.67 & .83 & 2 & \\
\hline & Ability to reconcile & 65 & 1.00 & 5.00 & 2.70 & .81 & 3 & \\
\hline & Ability to modify & 65 & 1.00 & 5.00 & 2.66 & .83 & 2 & \\
\hline \multirow[t]{5}{*}{ Internalising } & Ability to act & 65 & 1.00 & 5.00 & 2.75 & .79 & 3 & \multirow[t]{5}{*}{2.8} \\
\hline & Ability to practice & 65 & 1.00 & 5.00 & 2.66 & .87 & 2 & \\
\hline & Ability to incorporate & 65 & 1.00 & 5.00 & 2.68 & .89 & 3 & \\
\hline & Ability to acquire & 65 & 1.00 & 5.00 & 2.68 & .97 & 3 & \\
\hline & $\begin{array}{l}\text { Ability to be } \\
\text { consistent }\end{array}$ & 65 & 1.00 & 5.00 & 2.78 & .91 & 3 & \\
\hline
\end{tabular}


Table 5: Affective Skills' Development and Behaivours of Pupils in both schools.

\begin{tabular}{|c|c|c|c|c|c|}
\hline & \multirow[t]{2}{*}{ Behaiviours } & \multicolumn{2}{|c|}{ School 1} & \multicolumn{2}{|c|}{ School 2} \\
\hline & & $\begin{array}{l}\text { Total } \\
\text { Average } \\
\text { Mode }\end{array}$ & Remark & $\begin{array}{l}\text { Total } \\
\text { Average } \\
\text { Mode }\end{array}$ & Remark \\
\hline Receiving & $\begin{array}{l}\text { Open to experience or idea, willing to } \\
\text { hear }\end{array}$ & 2.2 & $\begin{array}{l}\text { Very } \\
\text { Often }\end{array}$ & 2.0 & $\begin{array}{l}\text { Very } \\
\text { Often }\end{array}$ \\
\hline Responding & Get involved in or participate actively & 2.8 & $\begin{array}{l}\text { Very } \\
\text { Often }\end{array}$ & 3.0 & Often \\
\hline Valuing & $\begin{array}{l}\text { Attack values and express personal } \\
\text { opinions }\end{array}$ & 3.0 & Often & 2.8 & $\begin{array}{l}\text { Very } \\
\text { Often }\end{array}$ \\
\hline Organisation & $\begin{array}{l}\text { Reconcile disparate elements or conflicts, } \\
\text { develop value systems }\end{array}$ & 3.0 & Often & 2.2 & $\begin{array}{l}\text { Very } \\
\text { Often }\end{array}$ \\
\hline Internalising & Adopt belief systems or philosophy & 3.0 & Often & 2.8 & $\begin{array}{l}\text { Very } \\
\text { Often }\end{array}$ \\
\hline & Total & 2.8 & Often & 2.7 & Often \\
\hline
\end{tabular}

Results show the affective skills' development and behaivours of pupils in both schools. The total average modal value of "receiving" (being open to experience or idea and willingness to hear) of pupils in school 1 is 2.2. (very often) while school 2 is 2.0 (very often). The ability of pupils in school 2 to get involved in or participate actively, that is "responding" is 3.0 (often) while responding of school 2 pupils is 3.0 (often). The total average modal value of "valuing" (the ability of pupils to attack values and express personal opinions) for school 1 is 3.0 (often) while school 2 is 2.2. (very often). Results show that often pupils reconcile disparate elements or conflicts, develop value systems. In the same vein, pupils in school 1 often adopt belief systems or philosophy which pupils of school two internalise very often. The sum average representing affective skills' development and behaivours of pupils in both schools shows that school 2 outperformed school 1 with 2.7 (often) to 2.8 (often).

\section{Discussion}

The study found out that most of the school resources that are needed to facilitate learning in school are not available and adequate in the two schools. Sequel to the first research objective of the study to investigate the availability of school resources in special schools in Osun State. It was revealed that school infrastructures such as black/whiteboard(s), assembly ground(s), school library(ies), sickbay, school bookshop(s), cafeteria(s), school hall(s), chapel(s), music studio(s) and art studio(s) were not available in both schools. Regarding the second objective of the study, that is, to determine the adequacy of available school resources in special schools in the study area, it is the case that most of the available school resources are lesser compared to the population of pupils in the special schools. For instance, School 1 has four (4) toilets and bathrooms to be used by more than 10 teachers, non-teachers, and 60 pupils at large. Sad still, school 2 has two toilets and bathrooms in all.

www.scirj.org

(C) 2020, Scientific Research Journal

http://dx.doi.org/10.31364/SCIRJ/v8.i9.2020.P0920806

This publication is licensed under Creative Commons Attribution CC BY. 
Studies (Ayodele, 2004), (Bingley, 2012), (Beth, 2016), etc. have shown that the affective skills of pupils especially pupils with special needs are best developed and managed when there are adequate social equipment and facilities in the schools. As such, the non-professional staff available in two special schools are insufficient as there is only one administrative assistant in school 2. This is indeed a big challenge to special schools in the study area. Special schools, much more than regular schools should be equipped with good and adequate non-human and human resources to aid learning among the pupils. Bingley (2012) asserted that every child is a unique, different, competent, and active learner whose potential needs to be encouraged and supported to become the best of his or her kind when there are non-human and human resources available to guide such child. It is therefore unfortunate to note that both schools used for the study do not have encumbrance clerk, accountant, cleaners, bus driver, school security, librarians, computer technician and school security of any kind. It shows that there is zero security for the pupils on their movement to and fro in the school except for teachers who are watchful enough to keep an eye on the pupils.

\section{Recommendations}

- Teachers and headteachers in charge of all school resources such as sporting facilities, vocational skills development facilities, documents, etc. should be taught and trained on the uses of such facilities.

- Teachers' reinforcement and motivation should be encouraged in special schools as this will continuously boost their morale to teach well as well as use the available school resources excellently.

- Parents/Guardians should ensure that children with special needs are loved at home in other to maintain the teachings of teachers in the school at home.

\section{References}

Adeleke G. (2016); Inclusive Education in Early Childhood Care, Development and Education, ECCE Training Manual, Institute of Education, Obafemi Awolowo University, Ile-Ife, Nigeria

Adunola, O. (2011). The Impact of Teachers' Teaching Methods on the Academic Performance of Primary School Pupils in Ijebu-Ode Local cut Area of Ogun State" Ego Booster Books,Ogun State, Nigeria.

Hooker J. \& Denker K. (2014). The Learning Loss Scale Assessment Tool; An Empirical Examination of Educational goals. Handbook II; Affective Domain. New York; David McKay Company.

Bingley (2012) Principal Professional Development National Center for Education Development Research

Bruns, B., Martinez, S., Naudeau, S., Pereira, V. (2010). Impact evaluation of Save the Children early childhood development program in Mozambique: Baseline results. Washington, DC: The World Bank

Hightower, A.M. (2011), “Improving student learning by supporting quality teaching: Key www.scirj.org

(C) 2020, Scientific Research Journal http://dx.doi.org/10.31364/SCIRJ/v8.i9.2020.P0920806

This publication is licensed under Creative Commons Attribution CC BY. 
issues, effective strategies," Editorial Projects in Education.

Tebabal, A. \& Kahssay, G. (2011), "The effects of student -centered approach in improving students' graphical interpretation skills and conceptual understanding of kinematical motion, " Lat. Am. J. Phy. Edu, 5(2): 374-381.

Thousand, J.S. and Villa, R.A. (2007) Accommodating for greater student variance. In M. Ainscow (ed) Effective Schools for All. London: Fulton.

Turnbull, H.R., Stowe, M., \& Huerta, N. (2007). Appropriate public education: The law and children with disabilities. Denver, Colorado: Love Publishing Company

Turnbull, H.R., Turnbull, A., Shank, \& Leal (2002). Exceptional Lives: Special Education in Today's Schools. Englewood Cliffs, NJ: Merrill. 